Review article

\title{
Ethnobotanical profiling of Asparagus aethiopicus L.
}

\section{Gaddeyya Gandipilli* and Esteru Rani Geddada}

Centre of Advanced Study, Department of Botany, Andhra University, Visakhapatnam-530003, Andhra Pradesh, India

*Corresponding Author: mycology.au@gmail.com

[Accepted: 28 April 2018]

\begin{abstract}
An ethnobotanical survey was conducted to collect the information and medicinal properties of Asparagus aethiopicus, a perennial monocot herb of Asparagaceae family. The plants were collected from the fields of Visakhapatnam District in the Andhra Pradesh state of India. The live specimens were used for the description of plants and some of the plant material was dried and stored for long term preservation of the species and for further study. The present study aimed to describe botanical aspects and medicinal value of the species.
\end{abstract}

Keywords: Asparagopsis aethiopicus L. - Sprenger asparagus - Asparagaceae - South Africa Ayurveda.

[Cite as: Gandipilli G \& Geddada ER (2018) Ethnobotanical profiling of Asparagus aethiopicus L. Tropical Plant Research 5(1): 116-120]

\section{INTRODUCTION}

The socio-economic and land use changes are happening very fast during these days and are responsible for the disappearance of the traditional knowledge about plants and their uses. Documenting and safeguarding traditional ecological knowledge have become central issues in the planning and management of natural resources. The relevance of this knowledge as far as increasing the daily living standards of rural populations is concerned, as well as in taking decisions regarding the sustainable use of plant resources, has frequently been noted (Benz et al. 2000, Shackleton et al. 2002). Asparagus is a very ancient crop and the ancient Greeks (200 BC) and Romans considered Asparagus as a medicinal plant for relieving toothache (Welbaum 2015). Today Asparagus has spread around the world and it is an important vegetable in over 60 countries, including many parts of Europe, Asia, Australia and New Zealand (FAOSTAT 2015). Asparagus aethiopicus L. is a perennial herb, commonly called as Sprenger's or Asparagus sprengeri, a weed native to South Africa. The species is a monocot in the family Asparagaceae, subfamily Asparagoideae (Chase et al. 2009). A. aethiopicus was originally described by Carl Linnaeus in 1767. The attribution "Sprenger's Asparagus" refers to Carl Ludwig Sprenger, a German Botanist who made it very popular in Europe as an ornamental plant. A. aethiopicus is often used as an ornamental plant and it is considered as an invasive weed in many locations in South Africa. The species A. aethiopicus has been confused with A. densiflorus, commonly found in Australia, now regarded as a separate species.

\section{ETHNOBOTANICAL ASPECTS}

The family name Asparagaceae was proposed by Jussieu, soon after the genus Asparagus was named by Linnaeus (Fellingham \& Meyer 1995). Aethiopicus is a Latinised version of Ethiopia, the name often used by Linnaeus to designate South Africa (Parson \& Cuthbertson 2001). The species A. aethiopicus has had many common names such as Basket asparagus, Bushy asparagus, Ground asparagus, Sprenger asparagus, Protasparagus, Emerald feather, Fern asparagus, Asparagus fern, Basket asparagus fern, Emerald asparagus fern, Ground asparagus fern, Ground fern, Regal fern, Sprengeri fern and Sprenger's asparagus fern. The species has several synonyms such as Asparagopsis aethiopica (L.) Kunth., Asparagus sprengeri Regel., Asparagopsis lancea (Thunb.) Kunth., Asparagus lanceus Thunb., Asparagus densiflorus (Kunth) Jessop., Asparagus myriocladus Baker., Protasparagus aethiopicus (L.) Oberm., Protasparagus densiflorus (Kunth) Oberm.

Asparagus aethiopicus has little significance as a noxious weed. It was reported as a weed of coastal sand 
dunes, riparian areas, open woodlands, rainforests and forest margins in sub-tropical, warmer temperate and tropical regions. It prefers sandy soils and usually also some shade, and occasionally found in parks, old gardens and disturbed sites. The speciesis native to Southeastern coastal regions of South Africa, Eastern Cape and the Northern Provinces, United States, Hawaii and Florida. This species widely naturalised in the coastal districts of eastern Australia.The species was native to a small region in southern Africa (i.e. Cape Province of South Africa) and previously known as A. densiflorus in Australia. A. aethiopicus grown in cooler climates and as indoor and outdoor as an ornamental garden plant. Two cultivar verities of A. aethiopicus are commonly found, namely Sprengeri and 'Meyeri'. The 'Sprengeri' (extensively studied by C.L. Sprenger) has a scrambling form with sparser foliage, while 'Meyeri' has more erect stems to $70 \mathrm{~cm}$ (28 in) and denser foliage. The ground asparagus fern (Asparagus aethiopicus 'Sprengeri') was widely cultivated as a garden plant, particularly in Eastern Australia. Another cultivar, known as foxtail asparagus fern (Asparagus aethiopicus 'Meyersii'), has also been widely cultivated in Australia.

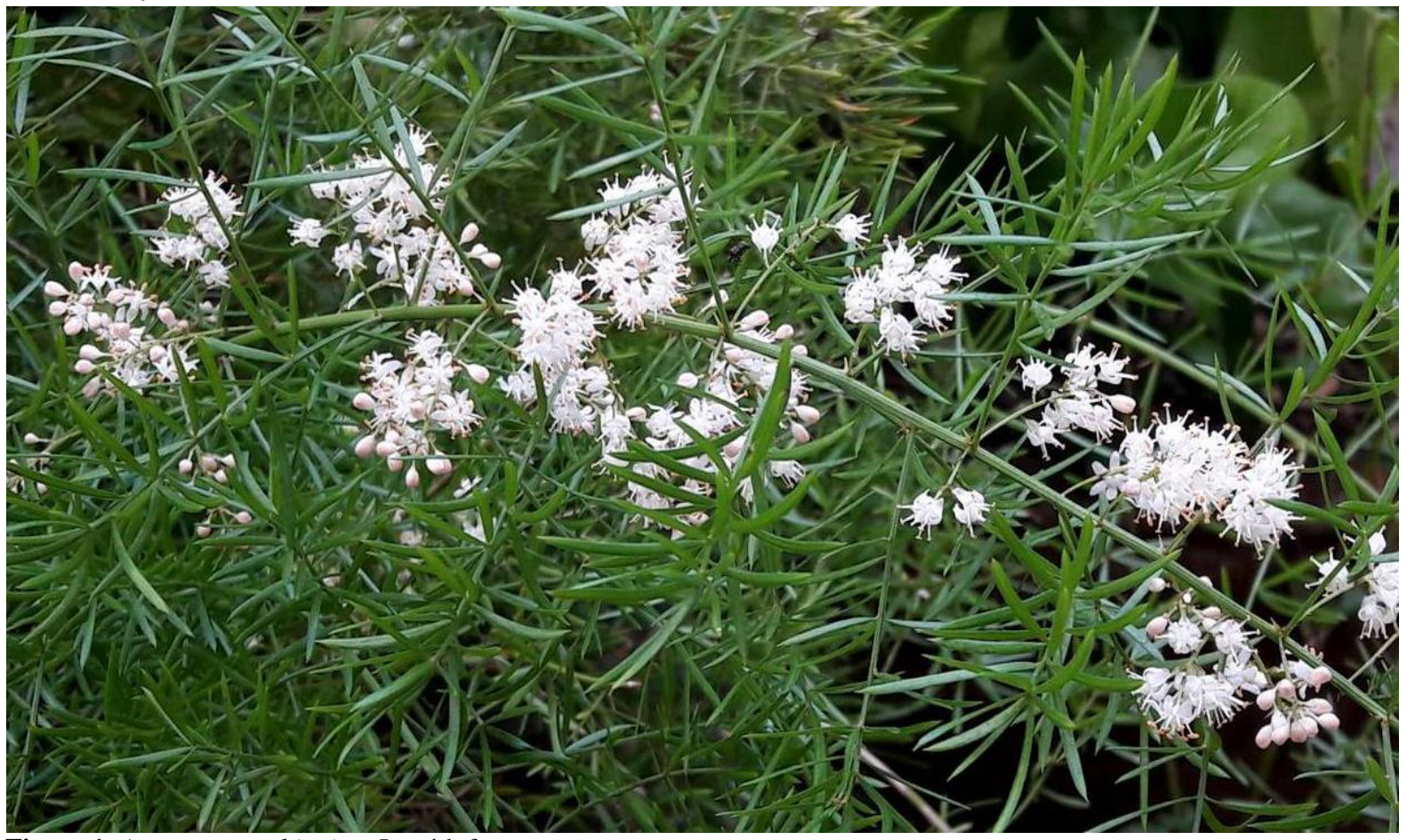

Figure 1. Asparagus aethiopicus L. with fern appearance.

Asparagus aethiopicus L. is a well branched perennial herb with tough green aerial stems, sparsely covered with spines. The leaves of the plant were actually leaf-like cladodes with $1-2 \mathrm{~cm}$ long and $0.1-0.2 \mathrm{~cm}$ wide, and arise in groups of four or more from the stem. Flowers small, white or pinkish white in colour and about $0.3-0.5$ $\mathrm{cm}$ long and arise in clusters on the stem during spring season. Flowers followed the summer by bearing small round berries $0.5 \mathrm{~cm}$ in diameter, which bear a black $3 \mathrm{~mm}$ diameter seed. The berries initially green and at maturity they turn to red colour in the winter. Fruits attract many birds for their food and the seeds are spread by fruit-eating birds. The root system formed a mat of fibrous roots with bulbous tubers (Fig. 1). A. aethiopicus isa long-lived (i.e. perennial), low-growing herb with spreading (i.e. erect to sprawling) or arching stems (up to $2 \mathrm{~m}$ long) that arise from a tuberous rootstock (Fig. 2). When growing up over other vegetation it can sometimes also climb up to $2 \mathrm{~m}$ in height. It has tall, woody, vigorous young stems, sometimes they twined. Rhizome-compact, bearing many long roots with side roots forming ellipsoid tubers (20 mm long), as well as a large network of white, branched rootlets. Stems- firm, smooth, woody, ribbed when young, pale. Spines- short, 10-20 mm long, exserted, recurved, hard. Branches- many, close together, fairly equal in length. Cladodes- 4 to 6 in a fascicle, terete or ridged, 10-40 mm long, 1.0-1.5 mm wide, apiculate, discoid at the base, glaucous green. Racemesmany, placed all along the branches, from basal side buds, usually exserted, simple or with some short branchlets. Petals- with the 3 outer perianth segments minutely ciliate, forming a long pericladium, white. Pedicels- short, subtended by bracts, both persisting after flowers have dropped off. Stamens- anthers orange in coloured. Ovary- dark, contracted below. The flourish period of the species is between the month of OctoberJune and the fruiting appeared at all over the year. This species reproduces by seed (Fig. 3) and also vegetatively 

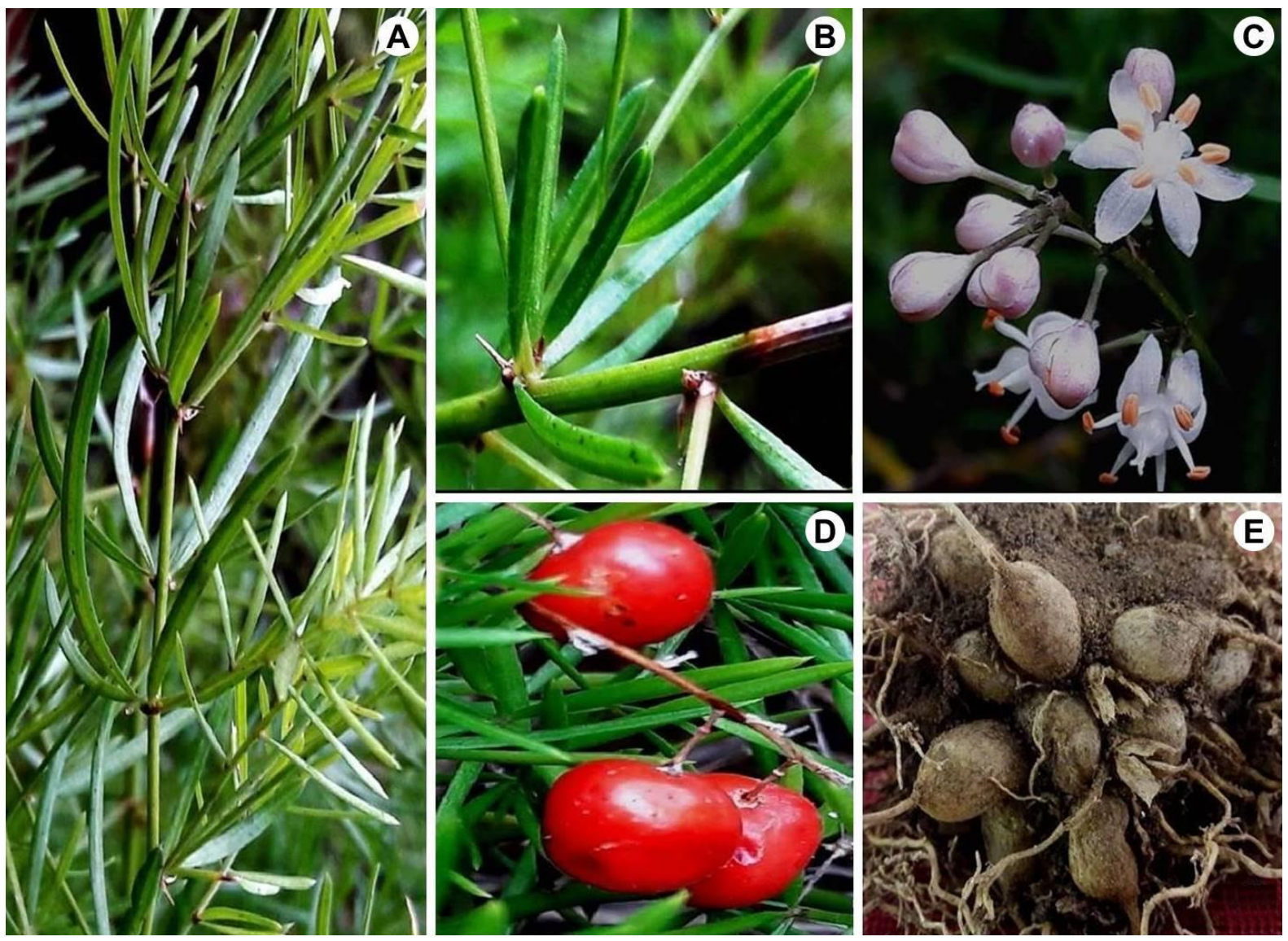

Figure 2. Asparagus aethiopicus L.: A, Branch; B, Cladodes; C, Flowering; D, Fruiting; E, Tuber roots.
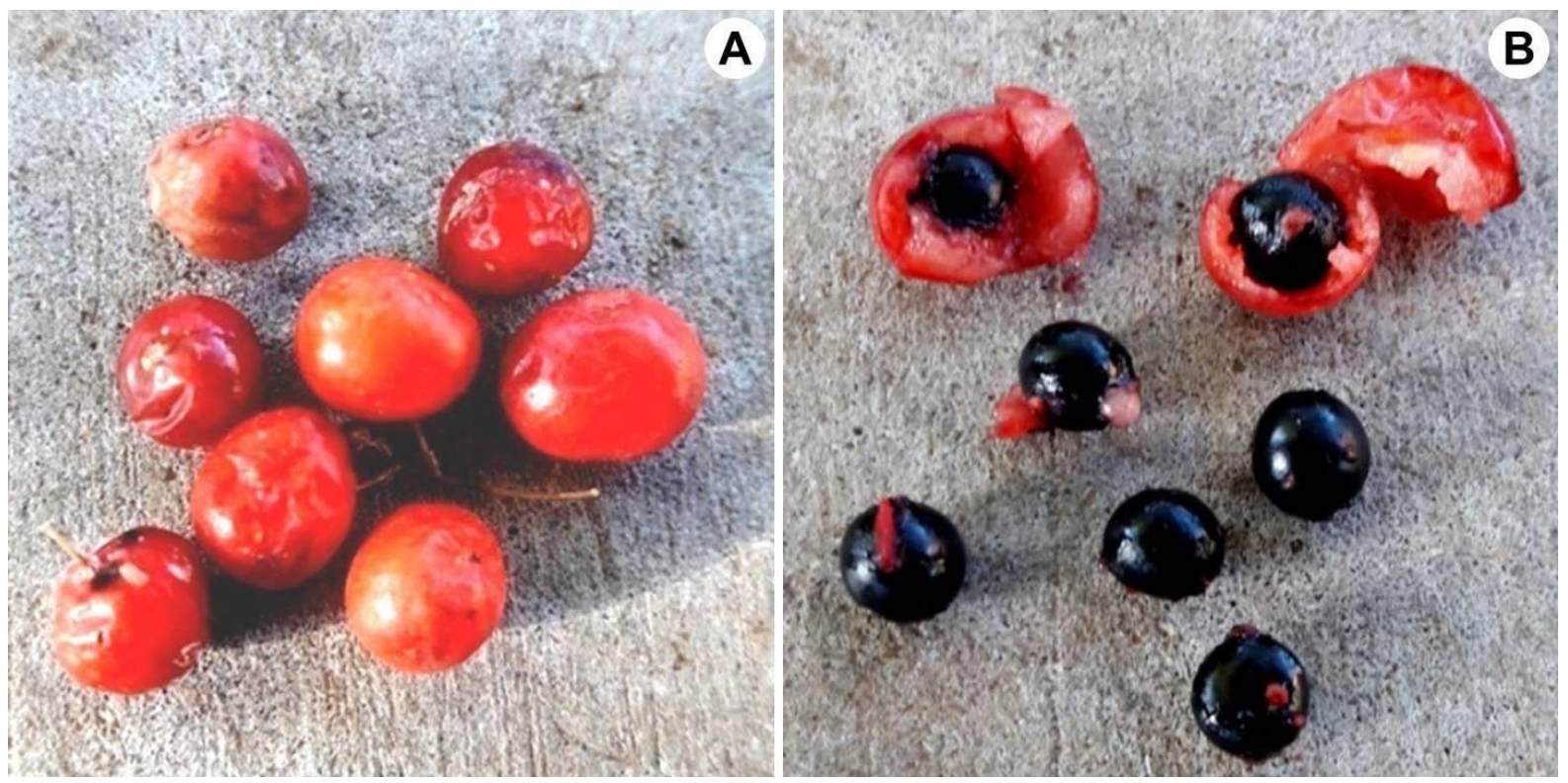

Figure 3. Asparagus aethiopicus L.: A, Fruits; B, Seeds.

by its creeping underground stems (i.e. rhizomes) and tubers. Its berries are readily eaten by birds and the seed contained within are thereby spread to new areas. Its seeds and underground tubers are also commonly dispersed in dumped garden waste. There are several species are similar to A. aethiopicus with certain morphological characteristics: Ground asparagus fern (Asparagus aethiopicus 'Sprengeri') has some similarities with other species of asparagus. They are climbing asparagus ferns (Asparagus africanus and Asparagus plumosus), bridal veil (Asparagus declinatus), bridal creeper (Asparagus asparagoides), garden asparagus (Asparagus officinalis), sickle thorn (Asparagus falcatus), Ming asparagus fern (Aspargaus retrofractus) and other asparagus ferns (Asparagus scandens and Asparagus virgatus). 


\section{MEDICINAL PROPERTIES}

In the developing countries, most of the population depends on the herbal medicines for primary healthcare needs (De Silva 1997). Asparagus species were used for multipurpose health benefits around the world. Leaves of asparagus were used to reduce body weight, to increase urination and to treat diabetes in South Africa (Afolayan \& Mbaebie 2010). Recently the investigation on Asparagus species was revealed that the plant might be useful t to cure severe HIV/AIDS related diseases in Zambia (Kazhila 2016). The root extract is used to treat diarrhea or dysentery at various parts of Pakistan also reported (Amjad et al. 2017). Out of several species of 'Asparagus' grown in India, Asparagus racemosus, Asparagus gonaclades and Asparagus adsendens are most commonly used in indigenous medicine. Mostly its tuberous roots are used in Ayurvedic medicines. The powdered dried root exhibits galactogogic properties; used for the preparation of nutritive tonic used in general sexual weakness. It is reported to be useful against diarrhea, dysentery and in general debility. Shatavari roots are used mainly as galactagogue which stimulates the secretion of breast milk. It is applied in improving the lost body weight and also known as an aphrodisiac. The root is useful in treating the ailments like dysentery, tuberculosis and diabetes. Commonly, it supports to maintain the health by giving immunity to diseases. It is considered as very good energy provider to the weak body system (Thakur \& Sharma 2015). Extensively the boiled tuberous roots of asparagus were used to animals and women to increase lactation (Shukla et al. 2010).

IDENTIFICATION KEY (Adopted from Gamble \& Fischer 1928).

1. Cladodes flattened, 2-3 mm wide and mostly $15 \mathrm{~mm}$ long; berry red 1.*A. aethiopicus $1 *$ Cladodes \pm terete, $0.5 \mathrm{~mm}$ diam; <10 mm long; berry black or orange

2. Final branches and cladodes in 1 plane; flowers and fruit terminal on lateral branchlets; Fruit black $2 *$ A. plumosus

$2 *$ Branches and Cladodes not in 1 plane; Flowers and Fruit axillary; fruit orange

3. Cladodes 3-7 at each node \pm erect and straight; Stem not pinoe. 3* A. virgatus

$3 *$ Cladodes $7-12$ at each node, spreading and often \pm curved, older stems spinose $4 *$ A. africanus

\section{RED LIST CATEGORY \& CRITERIA: LEAST CONCERN}

Asparagus aethiopicus L. currently rated as Least Concern of IUCN Red List species due to its large naturalized range and its status as a noxious weed in many parts of its range. There are no known current threats to this species in its native range (Monnier \& Staden 2013).

\section{DISCUSSION}

Asparagus aethiopicus L. was a prostrate perennial monocot commonly grown in the fields and especially wild localities of the study area. The species was categorized as Least Concern in IUCN Red List due to its large naturalized range and it was considered as a noxious weed in many parts of the world. The species was entered into India from Denmark and infested in several areas by seeds. However, the species were identified as medicinal plant from the ancient period of the world as well as in ancient Indian civilization. The plant has many medicinal properties and it'sknowledge should be enlightened to identify various drugs from the different parts of the plant.

\section{ACKNOWLEDGMENTS}

The authors were very grateful to local farmers, Agricultural Officers and Taxonomists of Andhra University for their contribution.

\section{REFERENCES}

Afolayan AJ \&Mbaebie BO (2010) Ethnobotanical study of medicinal plants used as anti-obesity remedies in Nkonkobe Municipality of South Africa. Phcog. Net.

Amjad MS, Arshad M, Saboor A, Page S \& Chaudhari SK (2017) Ethnobotanical profiling of the medicinal flora of Kotli, Azad Jammu and Kashmir, Pakistan: Empirical reflections on multinomial logit specifications. Asian Pacific Journal of Tropical Medicine 10(5): 503-514.

Benz BF, Cevallos J, Santana F, Rosales J \& Graff M (2000) Losing Knowledge about plant use in the Sierra de Manantian Biosphere Reserve, Mexico. Economic Botany 54: 183-191.

Chase MW, Reveal JL \& Fay MF (2009) Asubfamilial classification for the expanded asparagalean families Amaryllidaceae, Asparagaceae and Xanthorrhoeaceae. Botanical Journal of the Linnean Society 161: 132www.tropicalplantresearch.com 
136.

De Silva T (1997) Industrial utilization of medicinal plants in developing countries. In: Bodekar G, Bhat, KKS, Burlay J \& Vantomme P (eds) Medicinal plants for forest conservation and healthcare. Nonwood Forest Products, No 11, FAO, Rome, Italy, pp. 38-48.

FAOSTAT (2015) Statistical Database of the Food and Agriculture Organization of the United Nations. FAO, Rome.

Fellingham AC \& Meyer NL (1995) New combinations and a complete list of Asparagus species in southern Africa (Asparagaceae). Bothalia 25(2): 205-209.

Gamble JS \& Fischer CEC (1928) Flora of the presidency of Madras. (Part VIII- Ulmaceae to Xyridaceae). Adlard \& Son, Ltd, 21 Hart street, W.C. London.

Kazhila CC (2016) Ethnobotanical Study of Plants Used in the Management of HIV/AIDS-Related Diseases in Livingstone, Southern Province, Zambia. Evidence-Based Complementary and Alternative Medicine. Hindawi Publishing Corporation.

Monnier RF \& von Staden L (2013) Asparagus aethiopicus. The IUCN Red List of Threatened Species 2013, IUCN.

Parson WT \& Cuthbertson EG (2001) Noxious weeds of Australia. CSIRO Publishing, pp. 692.

Shackleton SE, Shackleton CM, Netshiluvhi TR, Geach BS, Balance A \& Fairbanks SHK (2002) Use patterns and value of savanna resources in three rural villages in South Africa. Economic Botany 56: 130-146.

Shukla AN, Srivastava S \& Rawat AKS (2010) An ethnobotanical study of medicinal plants of Rewa district, Madhya Pradesh. Indian Journal of Traditional Knowledge 9(1): 191-202.

Thakur S \& Sharma DR (2015) Review on medicinal plant: Asparagus adscendens Roxb. International Journal of Pharmaceutical Science and Health Care 5(3): 82-97.

Welbaum GE (2015) Vegetable Production and Practices. CABI, pp. 486. 